\title{
ЕСТЕТИЧНЕ НАВАНТАЖЕННЯ КОЛОРЕМ В ІНДИВІДУАЛЬНО-АВТОРСЬКІЙ КАРТИНІ СВІТУ М. КОЦЮБИНСЬКОГО
}

\author{
АЛЛА КОЩОВА \\ Одеський міжнародний гуманітарний університет, Одеса - Україна \\ ESTETYCZNY WALOR KOLORU W AUTORSKIM OBRAZIE ŚWIATA \\ MYCHAJŁA KOCIUBYNSKIEGO
}

AŁŁA KOSZCZOWA

Międzynarodowy Uniwersytet Humanistyczny w Odessie, Odessa — Ukraina

STRESZCZENIE. Artykuł poświęcony jest zaganieniu kolorystyki w dziełach literackich Mychajła Kociubynskiego. Dokonano analizy cech strukturalno-semantycznych oraz pola stylistycznego nazw kolorów w małej prozie pisarza. Ustalono aktywność użycia i wielofunkcjonalność kolorów w autorskim obrazie świata Mychajła Kociubynskiego.

\section{AESTHETIC LOADING OF COLOR IN M. KOTSYUBYNSKIY'S INDIVIDUAL AUTHOR'S WORLD MAPPING}

\author{
ALLA KOSHCHOVA \\ Odessa International Humanitarian University, Odessa - Ukraine
}

ABSTRACT. The article deals with the color palette of M. Kotsyubynskiy's compositions. The structural and semantic features and stylistic functioning of the names of colors in the short prose of the writer have been analyzed. The frequency of the usage and multi functionality of the names of color in M. Kotsyubynskiy's individual author's mapping of the world have been found out.

$\mathrm{Y}$

сучасній філологічній літературі художній текст розглядається з різних боків у багатьох наукових розвідках, оскільки є ,багатоаспектним та багатовимірним у плані його дослідження, що зумовлено смисловою багатоплановістю його лексичного наповнення"1.

Відома українська дослідниця Н. Сологуб зазначає, що художній текст „характеризується неоднозначністю семантики, множинністю інтерпретацій, що пояснюється використанням словесних знаків у їх вторинному кодовому значенні. Сугестивність художнього слова, зближення далеких уявлень, виникнення нових асоціативних і конототивних значень завжди присутні в художньому тексті"2.

У художньому мовленні активно вживаною $є$ група назв кольорів. У сучасній українській мові лексеми зі значенням кольору становлять окрему лексикосемантичну групу, якій властиві багатство значень та різноманітність функцій у художньому тексті. У лексико-семантичну групу назв кольорів входять назви основних кольорів та різних їхніх відтінків, що вказують на інтенсивність, міру вияву колірної якості тощо.

${ }^{1}$ I. М. Ба б і й, Колірна номінаиія і художній текст, [в:] Збірник наук. прачь, Київ 2005, с. 13.

${ }^{2}$ Н. М. Со ло г уб, Мовний портрет Яра Славутича, Київ 1999, с. 12-13. 
В останні десятиліття в сучасній лінгвістичній науці посилився дослідницький інтерес до вивчення семантики та естетичного функціонування назв кольорів у художньому тексті. Відомими дослідниками в галузі кольористики є I. Бабій, О. Дзівак, С. Срмоленко, А. Критенко, А. Кириченко, Н. Сологуб, Л. Пустовіт, Л. Ставицька та ін. Наше дослідження присвячено розгляду функціонування кольоронайменувань у творах М. Коцюбинського. Його твори насичені різними кольорами, виблискують різнобарв'ям та переливами світлотіней. Дослідники творчості М. Коцюбинського називали його „майстром, що віртуозно володів формою”, що „в нього не тільки досконала, а й прекрасна, позначена печаттю здорової краси, яка засвідчує велику закоханість письменника в життя”. М. Коцюбинська писала: „Лицар дійсності, Коцюбинський ніколи не був іiі рабом. Залишаючись на грунті факту, він прагнув відірватися від нього, знайти його ідейний, філософський, психологічний смисл, звести окремі спостереження у фокусі образного узагальнення. Ніде немає зовнішньої ілюстративности. Твори письменника - це книга життя, а не барвні малюнки до неї'4. Відсутність монографій, присвячених аналізу кольороназв у художніх текстах М. Коцюбинського, зумовлює актуальність запропонованого повідомлення.

Мета розвідки полягає в розгляді семантики та особливостей стилістичного функціонування назв кольорів у творах М. Коцюбинського. Об'єктом аналізу стали назви кольорів (колореми), а матеріалом послужила мала проза М. Коцюбинського.

У сучасній лінгвістиці назви кольорів традиційно поділяють на дві великі підгрупи: ,основних" назв (тонів) та ,другорядних” назв кольорів (барв) (А. Критенко, А. Кириченко, О. Дзівак, І. Бабій та ін.). Основними $є$ назви давнього походження, спільні для багатьох слов'янських мов (червоний, жовтий, зелений, голубий, синій, білий, чорний). „Другорядні” колореми вказують на інтенсивність кольору (синюватий, біластий, блідо-жовтий, світло-червоний, темно-зелений та ін.). Сюди ж відносять назви, утворені від лексем з інших тематичних груп (бузковий, кавовий, шоколадний, кремовий та ін.).

Відомий дослідник колірної лексики А. Критенко вказує, що ,у семантичній класифікації назв кольорів сучасної української мови окреме місце посідає група таких своєрідних назв, як: світлий, ясний, блискучий, осяйний, темний, тьмяний, смуглявий, загорілий, засмаглий, брудний, як прислівник поночі і дієслово поночіти (синоніми назв темно, темніти), а також група назв строкатих кольорів: строкатий, пістрявий, плямистий, рябий, яблукатий, картатий, гречаний, зозулястий, сорокуватий та ін. Ці „строкаті” назви відносять до категорії кольору на тій підставі, що й назви білий, чорний і сірий, мішанину яких вони виражають. Не можна поминути й групи назв на позначення неозначеного кольору: барвистий, різнобарвний, багатобарвний, прозорий, а також безбарвний. До системи назв кольорів певною мірою дотичними $\epsilon$ й такі слова, як холодний, теплий, гарячий, глухий, різкий, приглушений, крикливий, свіжий, пишний, соковитий, сухий, легкий, важкий, ніжний, веселий, похмурий, моторошний, що виражають кольорові відтінки предметів (насамперед, тканин та одягу) з боку їх дії на психіку людини".

${ }^{3}$ М. О. Костен ко, Художня майстерність М. М. Коиюбинського, Київ 1961, с. 4.

${ }^{4}$ М. Х. Коц юб и н с ь ка, Мої обрії в 2 m., Київ 2004, т. 1, с. 217.

${ }^{5}$ А. П. Кри те н ко, Семантична структура назв кольорів в украйнській мові, [в:] Славістичний збірник, Київ 1983, с. 99. 
Колореми називають ознаку предмета, тому основною граматичною формою їх вираження є прикметник. „Серед якісних прикметників української мови виділяють три основні генетично-структурні підгрупи, до кожної з яких входять прикметникові колореми" ". Першу підгрупу становлять прикметники, що виражають ознаку безпосередньо лексичним значенням своєї основи і $є$ давнього походження (білий, синій, зелений, блідий та ін.).

До другої підгрупи належать якісні прикметники, що виражають ознаку не безпосередньо, а через властивість іншого, якісно осмисленого поняття. Ці прикметники мають прозору етимологію, вони пізнішого походження й утворені від іменників, дієслів та інших частин мови за допомогою суфіксів, префіксів і шляхом осново- та словоскладання (русявий, голубоокий, чорноволосий та ін.).

Третя генетично-структурна підгрупа якісних прикметників формується з перших двох. Це складні прикметники на зразок: світло-зелений, ясно-голубий, чорно-білий, жовто-зелений та ін.

У малій прозі М. Коцюбинського виявляємо багато прикметникових колорем, що, крім називання основних кольорів, мають значення недостатнього або надмірного вияву колірної ознаки. На недостатній ступінь інтенсивності колірної ознаки вказують суфікси -уват-, -юват-, -оват-, -ав-, -яв-, -acm-, -ист-, напр.: „хвилі зливались, мов брили зеленкуватого скла"7 (На камені, 1, с. 374), „блідувате обличчя” (Лялечка, 1, с. 307), „біле, жовтаве од старості тіло” (Вiдьма, 1, с. 274) та ін.

Надмір вияву колірної ознаки в українській мові виражається ступенями порівняння (за допомогою суфіксів -ш-, -іш-, префікса най-, слів (більш, менш, найбільш, найменш): „Небо було синіше од моря, море було синіше од неба” (Intermezzo, 2, с. 198).

М. Коцюбинський активно вживає колореми, що містять суб'єктивну оцінку якості предмета. „У прикметниках, прислівниках і дієсловах категорія суб'єктивної оцінки виявляє себе в одному типі форм суб'єктивної оцінки у формах позитивної емоційності, пестливості"в. Такі форми творяться за допомогою суфіксів -еньк-, -есеньк-, -ісіньк- і под.: червоненький, зеленесенький та ін., напр. ,, в біленькій голівці її промайнула думка” (Харитя, 1, с. 35).

Крім прикметників, колірну ознаку можуть виражати й інші частини мови, a came:

- дієслова (біліти, жовтіти, червоніти);

- іменники (блакить, зелень, синь);

- прислівники (зелено, добіла).

У малій прозі М. Коцюбинського знаходимо випадки вираження колірної ознаки різними частинами мови: дієсловами (,світло од груби золотить протилежну стіну” (На віру, 1, с. 70); „Надворі сніг синів та грав вогнями” (Лялечка, 1, с. 317); іменниками (,Небо над Галаганом жевріло, як розпечене залізо; широка річка понялась на заході вогняною барвою, далі зарожевіла, засяяла блакиттю, а там заблищала сизою барвою холодної криці..." (Помстився, 1, с. 149); „Вітер стих, і чистий свіжий сніг сріблом сяяв під блакитним наметом неба" (Ялинка, 1, с. 97) та ін.

${ }^{6}$ Сучасна українська літературна мова. Морфологія, Київ 1969, с. 151.

${ }^{7}$ М. М. Ко ц ю б и н с ь к и й, Твори в 2 m., Київ 1963 - далі подаємо поклики на це видання в круглих дужках, зазначаючи назву твору, том, і сторінку.

${ }^{8}$ Сучасна украӥнська літературна..., с. 176. 
Іменникові колореми ,позначають насиченість, концентрованість певного кольору. Вони активно вживані у мові, зокрема у художній, де не тільки вказують на реальний колір зображуваних предметів і явищ, але й часто виступають важливим стилістичним засобом, тому що $є$ семантично конденсованішими й експресивнішими, ніж прикметникові кольороназви, напр.: „весняний регіт жене по небесній блакиті... білі хмаринки” та ін. Вони вносять відповідний емоційний заряд в оповідь",.

Крім простих за формою колорем, М. Коцюбинський активно вживає кольоронайменування композитної форми. Складні назви кольорів у художньому тексті письменник застосовує в портретних характеристиках, пейзажних замальовках тощо, напр.: світло-голубе небо, сіро-зелене поле, яскраво-жовтий звіробій, темно-синє море, біло-рожева квітка та ін.

Часто такі складні кольороназви передають відтінки кольорів, їхню якість, виражають ступінь інтенсивності, яскравості кольору. Подекуди подібні одиниці засвідчують поєднання двох назв кольорів і виражають проміжні кольори. Багатство, „шаленство” барв спостерігаємо в такому контексті: „Лежали у високій траві, серед моря квіток, і роздивлялись: там, на самому споді, жовтіли черевички і дрібна потентиля, як зерна золотого піску, а над ними здіймались топольки вероніки то сіро-блакитні, то густо-сині... а там знов волохата центаврія хилилась на всі чотири боки, немов хотіла засипать синьо-рожевим цвітом усі простори... А там, по луках, світила жовта кульбаба, як зорі на небі, крутилась на одній ніжці берізка, міцно тримався землі деревій, кивала сірими вітами собача рожа і на горохах сиділи, як метелі, біло-рожеві, червоно-сині і жовтогарячі квіти. Се була оргія квітів і трав, п’яний сон сонця, якесь шаленство кольорів, пахощів, форм...” (В дорозі, 2, с. 33-34). Такі колореми демонструють змішування кольорів, їхні переходи, зміни, сприяють точному, влучному втіленню картин зображуваної природи.

У кінці XIX - на початку XX ст. в українській літературі сформувалася тенденція описувати дійсність із застосуванням засобів, властивих різним видам мистецтв. Так, зорові й слухові образи використовували у своїй художній оповіді В. Стефаник, О. Кобилянська, Л. Українка та ін. М. Коцюбинський виробив власну стильову манеру. „Михайло Коцюбинський завжди перебував у стані художньої готовності. Усе життя його - це безперервний ланцюг активних спостережень і самоспостережень. Письменник у ньому владно заявив про свої права... Мав тонко розвинений літературний смак, надзвичайну широчінь і толерантність в розумінні художніх явищ", - писав Михайло Могилянський у спогадах про Коцюбинського. - Одного безперемінно вимагав від художника - безумовної щирости, маленької риси нещирости не міг пробачити. Лагідний та ласкавий у всьому, тут ставав суворий" ${ }^{\prime \prime}$.

У кінці XIX ст. став помітний розвиток психологічної прози. Особливістю ідіостилю М. Коцюбинського було заглиблення у внутрішній світ людини, настрій своїх персонажів, розкриття їхніх характерів у русі, динаміці. Усі зображувані ситуації, обставини у творі автор пропускає через психологічний стан своїх героїв, їхні характери розкриває через внутрішні душевні процеси. М. Коцюбинський як письменник-імпресіоніст описує не стільки дії персонажів на тлі природи, скільки передає враження від ії споглядання - зорових, звуко-

${ }^{9}$ I. М. Ба б і й, Іменники з колірною семантикою у сучасній украйнській мові, [в:] „Наукові записки", Сер. Мовознавство, Тернопіль 2000, вип. 2, с. 129.

${ }^{10} \mathrm{M}$. Х. Ко цю б и н с ь ка, зазн. джерело, с. 213. 
вих, запахових тощо. За допомогою них письменник вичерпно відтворює переживання, світосприймання персонажів.

Естетична функція світлотіні, кольору у творах М. Коцюбинського складна. Письменник уважав колір необхідним компонентом описів природи, портретів персонажів. Колореми в його творах є важливим виражальним засобом. Інколи М. Коцюбинський сам окреслював жанр своїх творів, називаючи їх акварелями, образками, етюдами. Крім того, сам автор був художником. Мабуть, тому йому вдавалися такі пластичні, соковиті пейзажні замальовки, влучні портрети тощо. Недарма М. Коцюбинського вважають неперевершеним майстром пейзажу.

В імпресіоністичній манері написані новели М. Коцюбинського Цвіт яблуні, Лялечка, На камені, Поєдинок. Однією з найкоштовніших перлин нашої літератури Іван Франко вважав новелу На камені. Твір уражає мальовничістю образів природи, пластичністю людських характерів. Тут помітне переплетення звукових і зорових образів, відчуттів; навіть звуки мають забарвлення: чорна тиша, сріблястий регіт мокрих листочків і под.

М. Коцюбинський назвав новелу На камені аквареллю, в ній переважають живописні образи. Письменник презентує мальовничі, колоритні картини моря й гір. Концептуальним є синій колір та його відтінки. Усе зображується на тлі блакитного неба, синього моря, синіх гір. Уже початок новели насичений такими барвами: „В одчинені вікна й двері на довгу, з колонками, веранду так і перлась ясна блакить моря, в нескінченність продовжена блакитним небом. Навіть душне повітря літньої днини приймало м'які синяві тони, в яких танули й розпливались контури далеких прибережних гір” (1, с. 373).

У новелі На камені описи природи підтверджують майстерність Коцюбинського-пейзажиста. М. Коцюбинська зауважує, що „письменник учить нас дивитися на природу „новими очима... ні, не новими, а тими, що довго спали під вагою безвладних повік (В дорозі). Він посилює, загострює об'єктивно існуючі риси, барви, подібності, кличе разом із собою у світ нових образних відкриттів" У його пейзажних замальовках необхідними та естетично вагомими стають зорові образи. Активне використання кольоронайменувань простежуємо в такому описі природи: „Зате за селом, у далекій перспективі, одкривався чарівний світ. В глибоких долинах, зелених од винограду і повних сизої імли, тіснились кам'яні громади, рожеві од вечірнього сонця або синіючі густим бором. Круті лисогори, мов велетенські шатра, кидали од себе чорну тінь, а далекі шпилі, сизо-блакитні, здавались зубцями застиглих хмар. Сонце часом спускало 3-за хмар у імлу, на дно долини, скісні пасма золотих ниток - i вони перетинали рожеві скелі, сині ліси, чорні важкі шатра та засвічували вогні на гострих шпилях" (с. 375-376). Подібний опис сам автор називає ,казковою панорамою”. Як бачимо, важливим зображувальним засобом тут є колореми.

В акварелі На камені переважають живописні образи. Ужиті назви кольорів виконують, крім зображальної, ще й оцінно-експресивну функцію. В описах картин моря й гір завжди присутня людина, їі життя. Пейзаж у творі органічно пов'язаний із подіями, розкриває психологічний стан героїв. Напр., у такому уривку: „Нема доріг навіть, бо як море розсердиться, то забирає єдину прибережну тропу... Тут тільки море, скрізь море. Вранці сліпить очі його блакить, удень гойдається зелена хвиля, вночі воно дихає, як слаба людина... В годину дратує своїм спокоєм, в негоду плює на берег, і б’ється, і реве, як звір, і не дає спати... Навіть в хату залазить його гострий дух, од якого нудить... Од нього

${ }^{11}$ Там само, с. 215. 
не втечеш, не сховаєшся... воно скрізь, воно дивиться на неї... Часом воно дрочиться: укриється білим, як сніг на горах, туманом; здається, нема його, щезло, а під туманом усе-таки б'ється, стогне, зітхає..." (с. 379).

Природа невіддільна від людського буття, людини, іï психологічного настрою. В оповіданні Ціпов'яз бідному селянину Семену, який купив землю, всміхалося навіть сонце: „Сонце стало ясне, веселе, умите і зараз-таки почало гратися з золотими стіжками жита й пшениці, що стояли, пишаючись на кожному обійсті" (1, с. 129).

М. Коцюбинський був неперевершеним портретистом. Описи зовнішності його персонажів є широкими, всебічними. Обов'язковим компонентом його портретів є кольоронайменування, напр., в описі дівчинки в оповіданні Харитя: „Любо було глянути на iї дрібненькі, запечені на сонці рученята, що жваво бігали від одної роботи до другої. Великі сиві очі з-під гарних вій дивилися пильно й розумно. Смугляве личенько розчервонілося, повні вуста розтулилися - вся увага іiі була звернена на роботу. Вона забула навіть і за нові червоні кісники, що двічі обмотували їі русяву, аж білу, голівку” (1, с. 34-35); описі зовнішності героя Алі в акварелі На камені: „Його струнка фігура в вузьких жовтих штанях та синій куртці, здоровий, засмалений морським вітром вид та червона хустка на голові прегарно обвивались на тлі блакитного моря. Алі скинув на пісок свою ношу і знов скочив у море, занурюючи мокрі рожеві листки в легку й білу, як збитий білок, піну, а далі миючи їх у чистій синій хвилі" (1, с. 74). У таких описах колореми виконують виразну характеристичну функцію.

Здійснений аналіз дає змогу зробити висновок, що колірна палітра творів М. Коцюбинського $є$ багатою й різноманітною. Його новели та оповідання виблискують світлими, яскравими фарбами. Для М. Коцюбинського колір $\epsilon$ необхідним компонентом вичерпної характеристики предметів і явищ, влучним елементом портретних описів, обов'язковою деталлю пейзажних замальовок. Аналіз колорем залишається перспективним напрямом мовознавчих досліджень. 